\title{
Knowledge and Perception of Afenmai Residents on Lassa Fever Outbreak in Nigeria
}

\author{
John A. Orhewere (Ph.D) ${ }^{1 *} \quad$ Lucky Idowu Ojo (Ph.D) ${ }^{2} \quad$ Afam P. Anikwe ${ }^{3}$ \\ Department of Mass Communication, School of Information and Communication Technology, Auchi \\ Polytechnic, Auchi
}

\begin{abstract}
The media as purveyors and carriers of information frequently examine issues of public health by publishing messages that could guide the audience to make informed decisions about their health. This study therefore, examined the knowledge and perception of Afenmai residents on lassa fever disease outbreak in Nigeria. Anchored on Agenda Setting and the Health Belief Model, the study relied on survey design with questionnaire as instruments of data collection. Multi-stage sampling technique was used to sample 400 respondents from a population of 1,317,655 persons selected from six local government areas: Akoko-Edo, Etsako-Central, EtsakoEast, Etsako-West, Owan-West, Owan-East, in Afenmai region of Edo state. Findings indicate that the Afenmai people are exposed to campaigns on lassa fever prevention and control and that there is a significant level of adoption of the transmitted campaign messages. Based on the findings of the study, the researchers conclude that there is significant difference in the perception of Afenmai residents on lassa fever pandemic in Nigeria. The researchers further concluded that the media played useful role in sensitizing the residents of the region on the virus. It therefore, recommended that government and media organizations should enhance media campaign messages on lassa fever outbreak in the county amongst others.
\end{abstract}

Keywords: Knowledge; Perception; Afenmai; Residents; Lassa Fever.

DOI: $10.7176 / \mathrm{NMMC} / 98-04$

Publication date:September $30^{\text {th }} 2021$

\section{Introduction}

The recent outbreak and resurgence of the dreadful and fast spreading lassa fever disease in parts of West Africa, particularly in Nigeria, Liberia, Sierra-Leone, Ghana and Guinea, constitute a major public health concern globally and therefore, calls for compulsive rethinking.

The disease, which medical and health practitioners often refer to as lassa haemorrhagic fever (LHF), is caused by the lassa virus, which according to Garret (2001), was first discovered in 1969, from a case in the town of Lassa, in Borno State, Nigeria. Lassa virus is zoonotic in that it spreads from rodents to man, specifically the multi-mammate rats (Walker, 1999).

According to Nigeria Centre for Disease Control (NCDC), May, 2018 report, from $1^{\text {st }}$ of January through $27^{\text {th }}$ of May, 2018, a total of 1,968 suspected cases have been reported from 21 states. Of these, 431 were confirmed positive with 108 deaths. Case fatality rate in confirmed cases is reported to be $25.1 \%$. Within this period of reporting, thirty-eight (38) health care workers have been affected in eight states - Ebonyi (16), Edo (12), Ondo (4), Kogi (2), Benue (1), Nasarawa (1), Taraba (1) and Abia (1) with nine deaths in Ebonyi (6), Kogi (1), Abia (1) and Ondo (1). Eleven months after the recent outbreak, i.e. by November 2018, 143 deaths have been recorded.

The NCDC adds that $81 \%$ of all confirmed cases are from Edo (42), Ondo (24\%) and Ebonyi (15\%). It further added that 5,327 contacts have been identified from 21 states. Of these, 82 symptomatic contacts have been identified, of which 28 (36\%) have tested positive from five states (Edo - 13, Ondo - 8, Ebonyi - 3, Kogi - 3 and Bauchi - 1). This figure shows that Ebonyi, Edo and Ondo are the most affected states. Afenmai region is reported to have the highest number of cases in Edo State.

Lassa fever is contagious and can be transmitted to humans via contact with food or household items contaminated with rodent urine or faeces. Just like malaria, lassa fever can present with fever, headache, sore throat and in rare cases, bleeding from the eyes, ears or nostrils.

In $80 \%$ of cases, the disease is asymptomatic, but in the remaining $20 \%$, it takes a complicated course. Mortality is said to be as high as $20 \%$ or higher among patients hospitalized with severe illness. The fever, it is also reported, accounts for up to one-third of deaths in hospitals within the affected regions and $10-16 \%$ of total cases. The current outbreak is said to be the worst outbreak ever reported since the 1969 first reported incident in the country.

The World Health Organization (WHO) assets that Lassa fever is a viral illness caused by rodents of the genus Mastomys, commonly known as the 'multimammate rat'. These rats are commonly found in grasslands or forests, urban areas and even inside houses throughout sub-samara Africa, which is why it's an endemic problem in the West African countries. These rodents are also commonly found in and around homes, feasting on leftover human food items or poorly stored food, which makes direct contact transmission fairly easy. They are also 
consumed as food by some communities.

A United States Center for Disease Control and Prevention (CDC), 2015 report indicates that the number of Lassa virus infections per year in the West Africa sub-region is crudely estimated at 100,000 to 300,000, with approximately 5,000 deaths yearly. The virus can be transmitted from one person to another through body fluids such as bloods and sperm. It can also be spread from infected rodents, contaminated surfaces or food. The infection of 27 health-care workers and 108 deaths in less than six months highlights the crucial need to strengthen infection prevention and control practices in all settings. The reporting of confirmed cases in 21 states of Nigeria indicates a risk of possible spread nationally.

Arising from these, WHO advises that prevention of Lassa fever relies on community engagement and the promotion of hygienic conditions to discourage rodents from entering homes. This according to WHO, can be achieved by practicing decent personal hygiene, i.e. wash your hands at all times, clean all surfaces with bleach, wash and cook all food items properly before eating and avoiding contact with the carrier rodents, disposing of garbage far from home, and banishing the urge to snack on rodents. Avoiding contact with the secretions of a contaminated person is a safe way to not get infected since there is no known vaccine yet for Lassa fever.

Early reporting saves life. A person suffering Lassa fever may have contact with relatives or care-givers and transmit the virus. To stop further transmission of the disease, all contacts of an infected person must be followed up for 21 days. That is how to confirm they were not infected. Health workers must maintain a high index of suspicion. Epidemiology has shown that more cases are recorded during the dry season in Nigeria.

Available public health records in Nigeria show that Nigeria has battled with lassa fever for about 49 years, yet the Institute of Lassa Fever Research and Control in Irrua Specialist Teaching Hospital (ISTH), Edo State, is the only specialist facility for the management of the disease in Nigeria. As at January, 2018, the Lassa fever ward was overflowing with victims so much that a makeshift tent had to be erected outside the ward to accommodate the growing number of cases.

The intermittent Lassa fever outbreak in Nigeria is of great concern because over 100 deaths have been recorded and reported by the NCDC since Monday, April 16, 2018, when 46 years old Gabriel Ambe, was reported to have died of Lassa fever at the Federal Medical Centre, Yola, Adamawa State. Ambe was alleged to have contacted the disease in Gembu, Sardauna Local Government Area of Taraba State.

By December 2017, the outbreak and overflow were only active in five states namely: Bauchi, Plateau, Edo, Ondo and Nasarawa. Four months later, April 2018, the outbreak of the disease has already killed 102 people with suspected cases spread across 21 states. According to the NCDC (2018) report, 81\% of all confirmed cases are from Edo State, with $46 \%$ of these coming from the Afenmai region. The vulnerability of health facilities in this region makes this very worrisome. More worrisome is the aspect of the NCDC's report that states that age 21 - 40 years is predominantly affected. Although, the incidence of Lassa fever seems to have taken the back seat since the emergence of Covid-19 and public attention swooped and diverted towards coronavirus disease because of its ravaging disposition, Lassa fever still remains one of the deadly diseases' mankind is contending with, and as such requires concerted efforts to nip it in the bud.

Also, studies have shown that Edo state has the highest prevalence of Lassa fever cases in Nigeria. Ironically, most people in Edo state, especially people in the rural areas, are not well informed about the pandemic. The implication is that victims are often brought to the hospital too late. Re-iterating the importance of massive enlightenment on Lassa fever, Adaka (2017) stated that people in Edo state are exposed to many risks of Lassa fever. A survey conducted recently in Etsako West Local Government area showed that 96.2\% of respondent $\mathrm{s}$ had seen rodents inside their houses. Nothing that not many Nigerian store their foods in rodentproof containers, contamination of food materials with rodent urine and faces is likely to occur. Still, in the study, it was found that many people do not keep their utensils away from rodent s, and do not bother to wash them before use. Buying of Garri from the open market and soaking them without refrying also constitute risk factors. This calls for education of the residents of Afenmai region on the dangers of Lassa fever.

Communication is an essential part of lassa fever control. The discipline of communication is dedicated to addressing critical social needs as well as improving lives through basic and applied research. Communication research is not just about studying how a message get $\mathrm{s}$ from one point to another; it focuses on hoe people use messages to inform, persuade, manage, relate and influence one another in various contexts and cultures, using a variety of channels and media (Poole \& Walther, 2001).

Mass media campaigns have been identified by scholars as one of the foremost channels capable of communicating information, increasing awareness and affecting a large number of people. Developing scholars have also recognized that in addition to mass media campaigns, media advocacy which centers on shaping public debate about public health, among other related variables can produce social, individual and behavioral changes to health issues on a grant scale. Kogah and Nwadiaro (2011) observed that the level of public engagement needed to control health challenges underscore the role of communication in disseminating information on the dangers to the world's public so that as informed citizens, people would be able to make decisions necessary to safeguard their health. All these point to the power of the mass media as a central tool in transmitting health 
information to the public.

To this end, Okoro, Ukonu, Eze and Odoemelam (2014) have posited that communication is critical to health intervention strategies, especially in helping to raise agenda on the intervention objectives of health issues, in this instance, lassa fever outbreak in Nigeria. Lastly, events in the past few decades have shown that the course of behaviour change communication is barely productive without mass media alliance. Also significant is the fact that any serious health communication that anticipates vital behavioural change requires the involvement and cooperation of the susceptible in the society using the mass media. This study therefore, became necessary considering the fact that the disease continues to constitute a threat of endemic proportion to human lives in Afenmai region of Edo State and the nation at large.

\section{Statement of the Problem}

It is largely believed that an informed laity helps in the promotion of good health practices in any community. The degree of awareness, seriousness and importance with which the general public hold health matters, ultimately play vital roles in achieving a healthy society. In modern society, promoting public health and preventing the spread of dangerous health risks has become an integral communication function. For any public health programme to succeed, the people for whom it is meant must understand the purpose of the system, how it operates and what roles they can play in order to make it possible for the system to function effectively.

Media advocacy theorists have suggested that beyond media campaigns and announcements, the media can promote structure and policies that support healthy lifestyles, since the media largely shape public debate and consequently, political and social interests. It is therefore, the conviction of this study that communication needs to be included in the process of Lassa fever control right from the start of activities and not as an after-thought or add-on at the end. Lassa fever communication should be integrated with other health education efforts, and these efforts should be strategically designed from an audience perspective to address the social and contextual environment as well as individual behaviours and knowledge.

Similarly, health communication can be well adopted and tilted to serve the function of awareness creation through which issues such as the knowledge and perception of Afenmai Residents on lassa fever outbreak in Nigeria can be determined. Furthermore, good government policies on health and even environmental issues can be conveyed to the public, and their understanding and acceptance.

Since the prevention and control of lassa fever can achieved through good government policies and programmes, its relevant agencies should formulate viable policies capable of preventing or controlling the incidence of Lassa fever in Nigeria. Sadly, most government policies, according to World Health Organization (2006) lack the people's support particularly in the developing countries as a result of non-inclusiveness of the people in the decision-making process. Ogunjimi (2012) corroborated this assertion when he pointed out that oftentimes, policies and programmes on infectious diseases in Africa countries are formulated and executed without adequate consultation with the people who the policies are meant to affect. Undoubtedly, communication through the media can be used to bridge the gap between the people and the government, thereby entrenching the needed synergy for a workable plan for prevention, control and perhaps eradication of infectious disease such as Lassa fever to thrive.

In addition, communication through media and even through interpersonal means can as well help to enlighten the public on effective prevention measures such as promoting good community hygiene, proper garbage disposal, far from homes, maintenance of clean households as well as storage of grains and other foodstuffs including refrying of Garri bought in the open market before soaking it. Also, the consequences of complacency on these preventive measures can be brought to the fore through horizontal and effective communication.

In all, this study is designed to help assess the knowledge and perception of Afenmai Residents on Lassa fever outbreak in Nigeria, using health communication as a tool. Moreover, how well the Afenmai Residents know the early and later symptoms of Lassa fever such as gastrointestinal, pharyngitis and cough, convulsion, facial oedema, pleural and pericardial effusions, bleeding from body openings and ultimately, coma are to be ascertained through this study.

More, Lassa fever campaigns in Nigeria have involved producing communication materials which are disseminated to the target audiences through organizational, institutional, mediated and interpersonal channels with the aim of influencing the beliefs, values and behaviour of the target audiences. However, the problem is that even though some aspects of communication have been used in lass fever control efforts in Nigeria, there are few research assessments of their efficacy.

Therefore, this research seeks to address the non-systematic evaluation of Lassa fever campaigns in Nigeria by assessing the knowledge and perceptions of the residents of Afenmai region of Edo State and the influences of such campaigns on them. 


\subsection{Objectives of the Study}

To determine the level of awareness of the residents of Afenmai region on Lassa fever outbreak in Nigeria

To determine the perception of the residents of Afenmai region on Lassa fever outbreak in Nigeria.

To determine the influences of Lassa fever campaigns on the residents of Afenmai region.

\subsection{Research Questions}

What is the level of awareness of the residents of Afenmai region on Lassa fever outbreak in Nigeria?

What is the perception of the residents of Afenmai region on Lassa fever outbreak in Nigeria?

What influence does the campaign on Lassa fever outbreak in Nigeria have on the residents of Afenmai region?

\subsection{Hypotheses}

$\mathrm{Ho}_{1} \quad$ There is no significant relationship between mass media coverage and the perception of Afenmai residents on lassa fever disease in Nigeria.

$\mathrm{Ho}_{2}$ There is no significant relationship between Afenmairesidents perception of lassa fever disease and their change of attitude towards the disease.

\subsection{Theoretical Leaning}

This study is anchored on Agenda Setting Theory and Health Belief Model. The agenda setting theory as propounded by Maxwell McCombs and Donald Shaw in 1972 assumes that the media sets agenda for the public on topical issues. It argues that 'most of the pictures in our heads, most of the things we think about and most of the issues we discuss are based on what we have read, listened to, or watched in different mass media' (Asemah, 2011, p.40). Wimmer and Dominick (2006, p. 254) avers that the theory proposes that the public agenda or what kind of things people discuss, think and worry about is shaped and directed by that the media choose to publicize.

The Agenda Setting theory is relevant to this study because it opines that the media are capable of setting agenda for Lassa fever prevention and control measures as public agenda with the view to engendering the necessary behavioural change. In essence, the mass media contents are capable of telling the audience to think about Lassa fever outbreak, its preventions and adopt the control measures.

The Health Belief Model (HBM) was developed in 1950s by a group of US Public Health Service Social Psychologist who investigated why few people took part in disease prevention and detection programme even if the service was without charge and in a different location (Hochbaum 1958, cited in Orji, 2019, p. 402). The model tries to explain people's health behaviour and possible reasons for their non-compliance with recommended health action. It also provides guidelines for programme development, allowing planners to understand and address the reasons for non-compliance. The thrust of the theory is that health behaviour is determined by personal beliefs or perceptions about a disease and the strategies available to decrease its occurrence. The model pointed out six main constructs that influence people's decision about whether to take action to prevent and/or control illness to include perceived susceptibility, perceived severity, perceived benefits, perceived barriers, cue to action and self-efficacy.

The relevance of this theory to the study is because it avers that an individual is most likely to engage in healthy behaviour such as eating hygienic foods and keeping the environment safe if he/she perceives same as vulnerable or susceptible to a Lassa fever threat; the protective action that is available is perceived to be effective and that the benefits of that action are seen as outweighing the perceived costs of the action (Bloor, 1995, in Ojih, 2019, p. 403).

\section{Literature and Empirical Reviews}

Since lassa fever was first discovered in Nigeria in 1969, at a village called Lassa in Borno state by a team led by Doctor Jordi Casals-Ariet after killing two missionaries, the disease has reoccurred at different times and places across the country. According to Buckley (1970) cited in Godeon (2013) and Ojih (2019, p. 403), the disease "was first isolated in 1969 from a missionary nurse who worked in a clinic in a small town, Lassa, in NorthEastern Nigeria. The nurse presumably acquired infection from an obstetrical patient residing in Lassa. She died approximately one week after the onset of symptoms. Subsequently, two more nurses that attended to the first patient contacted the disease leading to the death of one of them." The disease was thereafter, code-named after the village.

From 2016 when the first major Lassa fever outbreak in Nigeria occurred, the pandemic has been a national concern in need of media attention. Consequently, different bodies including the National Centre for Disease Control and Prevention (NCDC) in Nigeria, non-governmental agencies and individuals launched and sustained different campaigns on prevention, control and management of Lassa fever using different communication outlets including the mass media.

As part of its functions, the mass media has the responsibility of informing, educating and entertaining the society. In other instance, they are expected to serve as the watch dog of the society. These include mounting 
health surveillance so as to being health epidemics and related challenges to the attention of appropriate authorities and concerned individuals to be able to effectively and speedily manage it.

In Edo State and Afenmai region in particular, campaign messages on the prevention and control of lass fever outbreak are designed and disseminated through a variety of ways including radio, television, drama, talk shows, news features, columns, commentaries, editorials, social media, public service announcements, town criers, mobile announcements, posters and handbills, among others.

Communication, it has been widely argued, is effective only when the sender and the receiver have common meaning making the receiver to act as intended by the sender. It is against this backdrop that this inquiry was carried out to examine mass media audience exposure, their understanding, perception and adoption of Lassa fever prevention campaign messages in Afenmai region of Edo State, Nigeria.

Empirical evidence from studies in the area of media social roles suggest that the mass media have not sufficiently executed their surveillance function in the coverage of Lassa fever pandemic as well as have not influenced public knowledge sufficiently in this region. A recent study by Tobi, Asogun, Isah, Ugege \& Ebhodaghe (2013) investigated the knowledge and attitude towards Lassa fever among primary health care providers in Ekpoma, Edo State. Using descriptive survey method, structured questionnaire was administered to one hundred and thirty-five (135) health workers in Ekpoma. Findings showed that the respondents were generally ignorant of the existence of a vaccine for the disease. There was also was general lack of knowledge of the disease among the health workers. It was recommended in the study that the mass media should be used as a means of disseminating information on the prevention and control of such virus. The researchers advocated for urgent need to increase knowledge level among healthcare personnel on Lassa fever.

Olayinka, Omotoso, Osaretin\& Peter (2015) investigated the level of awareness of lass fever in Ijebu-Owo in Ondo State. Based on descriptive cross-sectional survey of 122 respondents in a semi-structured questionnaire, results showed that there is a low level of awareness and knowledge of Lassa fever among the studied population. Hence, the researchers recommend the need for further health education campaigns to improve environmental hygiene and a medication of practices that promote the spread of knowledge and awareness of Lassa fever. (Ojih, 2019, p. 404).

Again, Smith, Smith \&Adedeji (2017) studied the influence of the print media in the reportage of Lassa fever in Nigeria. They concentrated on the extent of media coverage in The Sun, The Guardian, The Nation and The Punch. The period of the study ranged from January to April 2016. Dwelling on ten topics randomly selected from 182 articles that were published between January 2016 to April, 2016, on lass fever, findings showed that month by month analysis of lass fever confirmed that January was the most reported month and April, the least reported. They recommended that newspaper coverage of Lassa fever continues all year round for effective awareness, prevention and control of the pandemic.

In a related study by Nwanguma and Anorue (2015) which examined audience response to media campaigns on Ebola Virus disease prevention and control in South-South Nigeria, the researchers x-rayed the level of audience exposure, awareness and perception to media campaigns on Ebola virus. Using survey research method with questionnaire as the instrument, the researchers randomly sampled 385 respondents from Rivers, Bayelsa and Delta states. They discovered that repeated exposure to media campaigns increases knowledge about the Ebola virus and result to behavioural change towards the disease. A greater percentage of the audience positively responded to the campaign. The researchers concluded that the mass media has been effective and play crucial role in the campaign against the outbreak of Ebola virus in South-South Nigeria. They recommended the need for adoption of mixed media strategy in disseminating health campaigns against the outbreak of deadly diseases to compliment the lapses found in other media campaign.

\section{Methodology}

This study adopted a quantitative research approach. Descriptive survey design was used to poll residents of Afenmai region of Edo State, who are the target of the study. The design is considered appropriate because the population is large and survey would help in choosing a representative sample of the population. Besides, the method is more convenient and cost effective and fulfilled the objectives of relating to public perceptions of Lassa fever outbreak in Nigeria.

The instrument for the collection of data for the study was a structured questionnaire. The study covered the six local government areas that make up the Afenmai region (Edo North), namely: Akoko-Edo, Etsako Central, Etsako East, Etsako West, Owan East and Owan West of Edo State.

A well-structured questionnaire was used to generate data for the survey. Three research assistants who took note and helped in documentation were engaged. Where necessary, they assisted in explaining issues to the participants.

The population of the study was 1,317, 655 persons resident in the region. This figure is a projection from the 2006 growth rate. According to Owuanmallam (2012), when the last recorded population of a country is far from the current, a projection should be done annually for the varied number of years. For Nigeria, he suggested 
an annual projection of $3.2 \%$ will be adequate. For this study, therefore, the projection was calculated at $3.2 \%$ annually for 12 years $(2006-2018)$

A sample size of 400 was drawn from the population using Taro Yamani's formula. The study adopted the multi-stage sampling technique using purposive, simple random and proportionate stratified sampling techniques to select the specific respondents for the study. In the first instance, and to allow for better spread, the six local government areas in the region were purposively considered in the selection of the constituents for the study. Three local government areas emerged from the sample randomization that followed. They include Akoko-Edo, with a population of 262,110; Etsako West, 197,609 and Owan East, 154,385. In each of the local government areas, two communities i.e., the local government headquarters and a village were purposively selected for the study. The decision to study a local government headquarter and a village is based on the understanding that a rural and an elite society view are necessary for the study. The respondents were reached on accidental basis. In all cases, a respondent must confirm that he/she is resident in the region before the questionnaire is served on $\operatorname{him} /$ her

Again, because of the variation in the population proportion of the three selected local governments, proportionate stratification was adopted to determine the number of copies of questionnaire that goes to the select local government areas based on the quotient of their population. The questionnaires were distributed as follows: Akoko-Edo, 166; Etsako West, 127; and Owan East, 107. Respondents were reached in major locations like the market places, motor parks/garages, restaurants, schools and offices.

Quantitative data extracted from the questionnaire administered were summarized in simple frequencies and percentages while presentation of data was done with the aid of tables and charts. The hypotheses set were validated with the help of Chi-Square $\left(\mathrm{x}^{2}\right)$ statistics.

\subsection{Presentation and Analysis of Data}

Out of the 400 copies of questionnaire distributed in the select areas, $378(94.5 \%)$ copies were returned and found useful. The presentation and analysis of data was therefore, based on the 378 copies of the questionnaire that were correctly filled and returned.

Research Question 1: What is the Level of Awareness of the Residents of Afenmai Region on Lassa Fever Outbreak in Nigeria?

Table 1 Respondents Level of Awareness

\begin{tabular}{|l|l|l|}
\hline Knowledge of & Lassa & Fever Pandemic \\
\hline Variable & Frequency & Percentage \\
\hline Yes & 364 & 96.3 \\
\hline No & 14 & $3.7 \%$ \\
\hline Total & 378 & $100 \%$ \\
\hline & & \\
\hline Level of Awareness & Frequency & Percentage \\
\hline Very High & 198 & $52.4 \%$ \\
\hline High & 112 & $29.6 \%$ \\
\hline Very Low & 32 & $8.5 \$$ \\
\hline Low & 36 & $9.5 \%$ \\
\hline Total & 378 & $100 \%$ \\
\hline
\end{tabular}

Table1 shows that residents of Afemai region are aware of lassa fever outbreak in Nigeria. The table also shows that the level of awareness is very high (198 or $52.4 \%$ and 112 or $29.6 \%$ ).

Research Question Two: What is the Perception of the Residents of Afenmai Region on Lassa Fever Outbreak in Nigeria.

Table 2: What is your Perception about Lassa Fever Outbreak in Nigeria?

\begin{tabular}{|l|c|c|}
\hline \multicolumn{1}{|c|}{ Option } & Frequency & Percentage \\
\hline It is a killer disease & 79 & $21 \%$ \\
\hline It is a disease associated with rats, dirty environment and people & 142 & $38 \%$ \\
\hline It is an infectious disease & 71 & $19 \%$ \\
\hline It is an abnormal and spiritually induced disease & 41 & $11 \%$ \\
\hline It is common among Africans & 45 & $12 \%$ \\
\hline Total & 378 & 100 \\
\hline
\end{tabular}

Table 2 indicates that 142 respondents representing 38\% believe that the disease is acquired through eating rat infested food and dirty environment while 79 respondents representing $21 \%$ of the population said that Lassa fever is a highly dreaded disease capable of killing its victim quickly. Also, 71 respondents or 19\% are of the view that Lassa fever is infectious. 
Table 3: Do you see Lassa Fever as a deadly disease?

\begin{tabular}{|l|c|c|}
\hline \multicolumn{1}{|c|}{ Options } & Frequency & Percentage \\
\hline Yes & 296 & $78.3 \%$ \\
\hline No & 58 & $15.3 \%$ \\
\hline Undecided & 24 & $6.3 \%$ \\
\hline Total & 378 & $100 \%$ \\
\hline
\end{tabular}

In table 3 above, 296 respondents representing 78.3\% agreed that lassa fever is a deadly disease while 58 respondents representing $15.3 \%$ said that lassa fever is not as deadly as people think.

Research Question 3: What Influence does the Campaign on Lassa Fever Outbreak in Nigeria have on the Residents of Afenmai Region?

Table 4: How would you Rate the Effectiveness or otherwise of Mass Media Messages During the Lassa Fever Outbreak?

\begin{tabular}{|l|c|c|}
\hline \multicolumn{1}{|c|}{ Options } & Frequency & Percentage \\
\hline Very Effective & 29 & $7.6 \%$ \\
\hline Effective & 212 & $56 \%$ \\
\hline Not Effective & 106 & $28 \%$ \\
\hline Undecided & 31 & $8 \%$ \\
\hline Total & 378 & $100 \%$ \\
\hline
\end{tabular}

Table 4 shows that 212 or $56 \%$ respondents are of the view that mass media messages were quite effective. Table 5: Do you believe that the Mass Media Messages received by Afenmai residents on lassa fever have contributed to change in attitude?

\begin{tabular}{|c|c|c|}
\hline Options & Frequency & Percentage \\
\hline Yes & 278 & $73.5 \%$ \\
\hline No & 64 & $17 \%$ \\
\hline Undecided & 30 & $10 \%$ \\
\hline Total & 378 & $100 \%$ \\
\hline
\end{tabular}

Table 5 shows that 278 or $73 \%$ respondents believe that the mass media messages have contributed in bringing about change in attitude of Afenmai residents with regard to Lassa fever disease.

Table 6: How useful are the health information messages from mass media to Afenmai residents?

\begin{tabular}{|l|l|l|}
\hline Options & Frequency & Percentage \\
\hline Very useful & 98 & 26 \\
\hline Useful & 254 & 62 \\
\hline Not useful & 26 & 12 \\
\hline None of the above & 0 & 0 \\
\hline Total & 378 & 100 \\
\hline
\end{tabular}

Table 6 above indicates that 98 or $26 \%$ of the respondents are of the opinion that health information emanating from the mass media is very useful while 254 or $62 \%$ agree useful.

\section{Test of Research Hypotheses}

\section{Research Hypothesis I}

Ho1 There is no significant relationship between mass media messages and the perception of Afenmai residents on Lassa fever disease.

It was tested based on data collected for the analysis of research questions in tables 2 and 4 respectively and the cross tabulation is given in table 7 .

Table 7: Mass media and the perception of Afenmai residents on Lassa fever disease Perception about Lassa Fever Disease/Channel of Mass Media Radio Television Newspaper Magazine Total Killer disease Disease associated with rats, dirty environment and people Infectious disease

Abnormal and spiritually induced disease

Common disease among Africans

Total

Source: Field Survey, 2019

Table 7.1 Result of Hypothesis 1

\begin{tabular}{|l|l|l|l|l|}
\hline Hypothesis & F.stat & df & Sig. & Remark \\
Perception & 2.385 & 4 & .109 & Not sig. \\
Media Channels & 2.529 & 3 & .107 & Not sig. \\
\hline
\end{tabular}


Table 7.1 reveals that no significant relationship between mass media and the perception of Afenmai residents on Lassa fever disease as the sig. values of perception and media channels responses were greater than 0.05 at $5 \%$ level of significant.

Table 7.2: Post Hoc Tests

Perception of Afemai residents on Lassa Fever disease

Multiple Comparisons

Dependent Variable: Response

\begin{tabular}{|c|c|c|c|c|c|}
\hline & $\begin{array}{l}\text { (I) Perception of Afemai } \\
\text { residents on Lassa Fever } \\
\text { disease }\end{array}$ & $\begin{array}{l}\text { (J) Perception of Afemai } \\
\text { residents on Lassa Fever } \\
\text { disease }\end{array}$ & $\begin{array}{l}\text { Mean } \\
\text { Difference (I- } \\
\text { J) }\end{array}$ & Sig. & Remark \\
\hline \multirow{2}{*}{ LSD } & \multirow{2}{*}{$\begin{array}{l}\text { Disease associated with rats, } \\
\text { dirty environment and } \\
\text { people }\end{array}$} & Killer disease & 14 & 0.095 & Not sig. \\
\hline & & Infectious disease & 14 & 0.095 & Not sig. \\
\hline & & $\begin{array}{l}\text { Abnormal and } \\
\text { spiritually induced } \\
\text { disease }\end{array}$ & $21.0000^{*}$ & 0.019 & Sig. \\
\hline & & $\begin{array}{l}\text { Common disease among } \\
\text { Africans }\end{array}$ & $20.2500^{*}$ & 0.022 & Sig. \\
\hline
\end{tabular}

Table 7.2 indicates that there are no differences in the response on the perception of Afenmai residents on Lassa fever as disease. However, there is significant difference in the perception of Afenmai residents on Lassa fever disease based on the disease is associated with rats, dirty environment and people; abnormal and spiritually induced disease and Common disease among Africans.

Table 7.3: Homogeneous Subsets

Response

\begin{tabular}{|c|c|c|c|c|}
\hline & \multirow{2}{*}{ Perception of Afemai residents on Lassa Fever disease } & \multirow{2}{*}{$\mathbf{N}$} & \multicolumn{2}{|l|}{ Subset } \\
\hline & & & 1 & 2 \\
\hline Duncan $^{\text {a }}$ & Abnormal and spiritually induced disease & 4 & 11.75 & \\
\hline & Common disease among Africans & 4 & 12.5 & \\
\hline & Killer disease & 4 & 18.75 & 18.75 \\
\hline & Infectious disease & 4 & 18.75 & 18.75 \\
\hline & $\begin{array}{l}\text { Disease associated with rats, dirty environment and } \\
\text { people }\end{array}$ & 4 & & 32.75 \\
\hline & Sig. & & 0.417 & 0.109 \\
\hline
\end{tabular}

In general, the perception of Afenmai residents on Lassa fever disease showed that the opinion is largely on disease is associated with rats, dirty environment and people followed by it is killer disease and infectious disease.

Hypothesis II:

Ho2 There is no significant relationship between Afenmairesidents perception of Lassa fever disease and their change of attitude towards the disease.

To address the hypothesis 2 , the research questions in tables 4 and 6 summarized in table 8 .

Table 8: Perception/Change of Attitude of Residents towards Lassa Fever Disease

\begin{tabular}{lllll}
\hline Perception/Change of & Yes & No & Undecided & Total
\end{tabular}

Attitude of Residents towards Lassa

Fever Disease

\begin{tabular}{|c|c|c|c|c|}
\hline High & 145 & 88 & 45 & 278 \\
\hline Low & 13 & 32 & 13 & 58 \\
\hline Very low & 14 & 15 & 13 & 42 \\
\hline Total & 172 & 135 & 71 & 378 \\
\hline
\end{tabular}

Source: Field Survey, 2019

Table 8.1 Result of Hypothesis 2

\begin{tabular}{|l|l|l|l|l|}
\hline Hypothesis & F.stat & df & Sig. & Remark \\
Perception & 6.561 & 2 & .055 & Sig. \\
Change Attitude & .985 & 2 & .449 & Not sig. \\
\hline
\end{tabular}

Table 8.1 reveals that significant difference was found among Afenmai residents' perception of Lassa fever disease but there is no significant difference in the change of attitude of Afenmai residents towards Lassa fever disease. This implies that differences exist in the perception of residents on Lassa fever disease. However, attitudinal change towards lassa fever disease remain the same among the residents based on this result. 
Table 8.2: Post Hoc Tests

Perception of Lassa Fever as a Deadly Disease

Multiple comparisons

Dependent Variable Response

\begin{tabular}{|l|l|l|l|l|l|}
\hline & $\begin{array}{l}\text { I) Perception on } \\
\text { Lassa Fever as a } \\
\text { Deadly Disease }\end{array}$ & $\begin{array}{l}\text { (J) Perception on } \\
\text { Lassa Fever as a } \\
\text { Deadly Disease }\end{array}$ & Mean Difference (I-J) & Sig. & Remark \\
\hline LSD & High & Low & $73.3333^{*}$ & $\mathbf{0 . 0 4 S i g . ~}$ \\
\hline
\end{tabular}

Perception evaluation in table 8.2 suggest that there are differences in the response among perception of Afenmai residents on Lassa fever.

Table 8.3 Homogenous Subsets

Response

\begin{tabular}{|l|l|l|l|l|}
\hline & $\begin{array}{l}\text { Perception on Lassa Fever as a } \\
\text { Deadly Disease }\end{array}$ & \multicolumn{2}{|l|}{ Subset } \\
\cline { 2 - 5 } & Very low & 3 & 1 & 2 \\
\hline \multirow{5}{*}{ Duncan $^{\text {a }}$} & Low & 3 & 14 & \\
\cline { 2 - 6 } & High & 3 & & 92.6667 \\
\cline { 2 - 5 } & Sig. & & $\mathbf{3 . 8 3 7}$ & $\mathbf{1 . 0 0 0}$ \\
\hline
\end{tabular}

In general, the Perception on Lassa Fever as a Deadly Disease is relatively high.

Change in attitude towards Lassa Fever Outbreak

Multiple comparisons

Dependent Variable Response

\begin{tabular}{|l|l|l|l|r|r|}
\hline & $\begin{array}{l}\text { I) Change in attitude } \\
\text { towards Lassa Fever } \\
\text { Outbreak }\end{array}$ & $\begin{array}{l}\text { (J) Change in attitude } \\
\text { towards Lassa Fever } \\
\text { Outbreak }\end{array}$ & $\begin{array}{l}\text { Mean Difference } \\
\text { (I-J) }\end{array}$ & Sig. & \\
\hline LSD & Yes & No & $\mathbf{1 2 . 3 3 3 3}$ & $\mathbf{0 . 6 3 8}$ & Not sig. \\
\cline { 2 - 5 } & Undecided & $\mathbf{3 3 . 6 6 6 7}$ & $\mathbf{0 . 2 3 8}$ & Not sig. \\
\hline
\end{tabular}

In terms of change in attitude towards Lassa Fever Outbreak of Afenmai residents on Lassa fever table 8.3 reveals that there is no significance change in the attitude towards Lassa Fever Outbreak in Edo North.

Table 8.4: Homogenous Subsets

Response

\begin{tabular}{|l|l|l|l|}
\hline & Change in attitude towards Lassa Fever Outbreak & Subset \\
\hline & & 1 \\
\hline \multirow{3}{*}{ Duncan $^{\mathrm{a}}$} & Undecided & 3 & 23.6667 \\
\cline { 2 - 5 } & No & 3 & 45 \\
\cline { 2 - 5 } & Yes & 3 & 57.3333 \\
\cline { 2 - 5 } & Sig. & 0.244 \\
\hline
\end{tabular}

\section{Discussion of Findings}

Research Question One: What is the level of awareness of the residents of Afenmai region on Lassa Fever outbreak in Nigeria.

Table 1 shows that the residents of Afenmai region have knowledge of lassa fever pandemic. The table also shows that the level of awareness of the residents of Afenmai region on Lassa fever outbreak in Nigeria is very high and high respectively (198 or $52.4 \%$ and 112 or $29.6 \%$ ). This suggests the high level of awareness created by the mass media and other relevant information sources on the outbreak of Lassa fever in Nigeria. It supports the argument that in the dissemination of information concerning positive behavioural change to members of the society, the mass media as noted by Asemah (2011) are tools for the transfer of information, concepts and ideas, to both general and specific audiences. The findings of this study also agrees with the findings of the study by Nwanguma and Anorue (2015) who noted that repeated exposure to media campaigns increases knowledge about Ebola virus and result to behavioural change towards the disease. The media are thus suitable tools in advancing public health goals, creating awareness and knowledge, changes in attitudes behaviours and perceptions of social norms.

Research Question Two: What is the perception of residents of Afenmai region on Lassa fever outbreak in Nigeria?

As shown in table 2, most residents of Afenmai believe that Lassa fever is a disease associated with rats and dirty environment. 142 respondents (38\%) gave this indication while 79 or $(21 \%)$ of agree that lassa fever is a killer disease. Also, 71 or $19 \%$ of the respondents concurred that lassa fever is an infectious disease while 41 
$(11 \%)$ of the respondents said it is an abnormal and spiritually induced disease. 45 or $12 \%$ of the respondents posited that lassa fever is a common disease in Africa. What this shows is that residents of Afenmai have different perceptions of the dreaded lassa fever disease. The health believe model adopted for this study is very relevant to this finding because it assumes that "health behaviour is determined by personal beliefs or perceptions about a disease and the strategies available to decrease its occurrence.

Research Question Three: What Influence does the Campaign on Lassa Fever Outbreak in Nigeria have on the Residents of Afenmai Region?

As shown on table 4, mass media messages were effective (29 or $7.6 \%$ and 212 or $56 \%$ ) with regards to influencing the residents of Afenmai region on lassa fever pandemic in Nigeria. However, table 6 shows the level of usefulness and the influence exerted by media messages on Afenmai residents on Lassa fever pandemic in Nigeria.

\section{Conclusion}

This study examined the knowledge and perception of Afemai residents on lassa fever outbreak in Nigeria. The objective was to determine the level of awareness of the residents of Afenmai region on lassa fever outbreak in Nigeria, to determine the perception of the residents of the region on the pandemic and to determine the influences of the lassa fever campaigns on same.

Findings from the study show that the level of awareness of the residents of Afenmai region on the lassa fever pandemic is very high. Findings also show that there is a difference in the perception of Afenmai residents on Lassa fever disease in Nigeria. Lastly, findings of the study shows that the mass media campaigns on lassa fever pandemic in Nigeria is highly effective.

Data gathered and analyzed for the study also show that there is some Changes in the attitude of the respondents towards lassa fever issues among Afenmai residents but with little significance. These findings corroborate Kogah and Nwadiaro (2011) findings that the level of public engagement needed to control health challenges underscore the role of communication in disseminating information on the dangers to the world's public so that as informed citizens, people would be able to make decisions necessary to safeguard their health through attitudinal change.

Based on the data gathered and the findings of the study, the researchers concludes that the mass media played a significant role in sensitizing the residents of Afenmai region about the outbreak of lassa fever disease in Nigeria. Part of the sensitization campaign was to inform the residents of Afenmai about the need to take precautionary measures that would help them avert contacting the lassa fever disease. This is in line with the agenda setting function of the mass media.

\section{Recommendations}

Arising from the findings of the study, the researchers make the following recommendations:

For a very effective motivation and behaviour change, experts in Behavior Change Communication (BCC) should be consulted when campaign on health issues or other emergencies are being planned in other to properly design the communications.

To improve the influence of media campaigns on health issues and promote positive health outcomes in Nigeria, media organizations should embrace and adopt behaviour change communication (BCC) approach and aggressively embark on health education campaigns too.

Government and the media should intensify media messages on lassa fever in the country, particularly in the rural areas where more aggressive sensitization is needed to help combat and eradicate ignorance through well-orchestrated campaign that runs for a reasonable time frame. This is vital because the agenda setting theory adopted for this study assumes that the more attention the media give to a topic, the greater the importance attributed to it by the media audience.

\section{References}

Adaka, S.O. (2017). Disease control, African environment and the people: A detailed assessment. An unpublished Ph.D. Thesis of the Department of Medical Sciences, Enugu State University of Science and Technology.

Aitken-Swan, J. \& Patterson, R. (1955).The cancer patient: delay in seeking advice. Br. Med. J. 623 - 627

Gladom, B. (1989). Survey of presentation of health matters by Nigerian newspapers. In Ralp A. Akinfeleye (ed) Health Communication and Development. Pp. 97 - 103. Ibadan: Spectrum Books Limited.

Batta, H. (2013). Health communication issues. In Des Wilson \& Herbert Batta (ed) Science, health \& environmental communication global issues \& local perspectives. Pp. $131-168$.

Brawly, E.A. \& Martinez-Brawley, E.E. (1999).Promoting social justice in partnership with the mass media.Journal of Sociology \& Social Welfare, 26)2), 63 - 86.

Cohen, B. (1962). The press, the public and foreign policy: Princeton NJ: Princeton University Press. 
Day, S. Dort, P. V. and Tay-Teo, K. (2010).Improving participation in cancer screening programs: A review of social cognitive models, factors affecting participation and strategies to improve participation. Carton South: Victorian Cytology Service.

Durosimi-Etti, F.A. (1985). Cancer patients in Nigeria - causes of delay in diagnosis and treatment. Niger. QJ. Hosp. Med. 3:28-30. In RalpAkinfeleye (ed) Health Communication and Development pp. 97 - 102. Ibadan: Spectrum Books Limited.

Elegbe, O. (2014). Challenges to sexual health information seeking behaviour among adolescents in Nigeria. In Eserinune McCarty Mojaye (ed) Journal of Communication and Media Researchvol.1 6 No. 1 pp. 83 - 97.

Garret, D. (2001).Exploring effective disease control measures in Africa.In Journal of Health and Medical Sciences No. 22, pp. 102 - 106.

Glanz, K. \&Rimer, B.K. (1995).Theory at a glance: A guide to health promotion practice. Bethesda MD: National Cancer Institute. HIH Publ.

John E. J., Guadalupe, X.A. and Stewart, H. (1999). "Theories and intervention approaches to health behavior change in primary care>" American Journal of Preventive Medicine; 17 (4): 275 - 284.

Kogah, V.C. and Nwadiaro, E.C.C. (2011), Broadcasting and health promotion: strategies for curbing the spread of contagious diseases in Nigeria. European Journal of Social Sciences, 21(2)

McCombs, M. and Shaw, D. (1972)."The agenda setting function of the press" Public Opinion Quarterly, 36: 32- 41.

National Institute of Health, (2005).Theory at a glance: A guide for health promotion practice. Washington, DC: National Institute of Health Publication, No. 05-3896.

Okoro, N., Ukonu, M.O., Eze, G.N. and Odoemelam, C.C. (2014). Press coverage of the expanded programme on immunization in Nigeria. A content analysis of the guardian, the sun and thisday newspapers. In NnanyelugoOkoro, Michael Ukonu, Anthony Ekwueme, ChidiebereNwachukwu and IjeomaOkeke (ed) pp. 91 - 104. ACCE 16 ${ }^{\text {th }}$ Annual Conference/AGM Conference Proceedings

Walker, P.E. (1999). National disease control and the local environment: issues and challenges. Lagos: Adek Publishers.

WHO (2012) ."Health education" http://www.who.int/topics/healtheducation/en/.Retrieved, 